\title{
PERAN ORANG TUA DALAM PEMBELAJARAN DARI RUMAH MASA PANDEMI COVID-19
}

\author{
Baiq Ida Astini' ${ }^{1}$, Aqodiah ${ }^{2}$ \\ 1Program Studi PGMI, ${ }^{2}$ Program Studi PGMI, Universitas Muhammadiyah Mataram, Indonesia \\ astinibaiqida@gmail.com ${ }^{1}$, aqodiah@gmail.com ${ }^{2}$
}

\section{INFO ARTIKEL}

\section{Riwayat Artikel:}

Diterima: 02-03-2021

Disetujui: 30-04 -2021

\section{Kata Kunci:}

Peran orang tua

Pembelajaran dari rumah

Covid - 19

\section{Keywords:}

Role of parents

Learning from home

Covid-19

\begin{abstract}
ABSTRAK
Abstrak:

Penelitian ini bertujuan untuk mengetahui peran orang tua dalam pembelajaran dari rumah masa pandemi Covid-19, di BTN Griya Praja Asri Desa Jatisela. Penelitian ini merupakan penelitian kualitatif melalui pendekatan deskriptif dengan subjek penelitian yaitu orang tua,siswa, dan guru. Pengumpulan data diambil melalui wawancara, observasi, dokumentasi. Hasil penelitian menunjukkan bahwa adanya peran orang tua dalam pembelajaran dari rumah masa pandemi Covid-19 di BTN Griya Praja Asri Desa Jatisela sebagai penyedia fasilitas belajar, membimbing dan mengawasi aktivitas belajar siswa, menyediakan waktu khusus untuk membimbing putra-putri mereka terkait pembelajaran dan tugas atau latihan yang diberikan guru, memberikan semangat dan motivasi, serta mengarahkan anak sesuai dengan bakat dan minat yang dimiliki oleh masing-masing anak
\end{abstract}

\begin{abstract}
This study aims to determine the role of parents in learning from home during the Covid-19 pandemic at BTN Griya Praja Asri. Jatisela Village This research is a qualitative descriptive approach with subjects namely parents, students, and teachers. Data collection is taken through interviews, observation, documentation. The results showed that is 1) the role of parents in learning from home during the Covid-19 pandemic at BTN Griya Praja Asri Jatisela Village, as a provider of learning facilities, guiding and supervising student learning activities, providing special time to guide their children regarding learning and assignments or exercises given by the teacher, providing enthusiasm and motivation, and directing children according to their respective talents and interests.
\end{abstract}

\section{A. LATAR BELAKANG}

Virus corona merupakan keluarga virus yang menyebabkan penyakit pada manusia yang menyerang saluran pernapasan, Wabah covid 19 telahmengubah pola pendidikan tidak hanya di dunia tetapi juga di Indonesia, yang mengharuskan setiap unsur pendidikan mengikuti protokolpencegahan covid-19 salah satunya dengan kebijakan belajardirumah. Sehingga pembelajaran pada anak dilakukan dengan daring atau jarak jauh dengan bimbingan orang tua (Mela Arnani: 2020).

Partisipasi orang tua sangat dibutuhkan agar pembelajaran dari rumah dapat terlaksana dengan optimal, karena dengan adanya kebijakan kegiatan belajar dari rumah untuk mengantisipasi pencegahan virus corona orang tua diharuskan menjadi pemantau sekaligus pembimbing siswa. Hal ini terkait dengan peran orang tua sebagai penyedia fasilitas belajar, motivator, juga secara tidak langsungmenjadi pengganti peran guru dalam membimbing dan mengawasi proses belajar siswa di rumah. Meskipun dalam hal ini banyak tantangan dan kendala yang dihadapi baik oleh orang tua, siswa maupun guru terkait pembelajaran dari rumah namun dengan pola komunikasi yang baik maka setiap permasalahan akan dapat diselesaikan.

Dalam kondisi seperti saat ini, disadari atau tidak, para orang tua menjalankan peran ganda pendidikan. Pertama, peran utama orang tua. Secara universal, para orang tua dituntut memikirkan dan merealisasikan pendidikan terbaik bagi anak-anak mereka, kewajiban ini melekat pada setiap individu orang tua. Sebab hadirnya buah hati adalah sebagai penerus harapan dan masa depan keluarga dan juga peradaban sebuah bangsa. Maka jelaslah orang tua harus memastikan, melalui teladan, anaknya menjadi baik dari sisi kepribadian, keilmuan dan juga masa depan. Kedua, peran tambahan orang tua. Peran tambahan ini muncul seiring pembatasan sosial. Belajar dan bekerja di rumah 
menjad isolusi yang tak terelakkan. Partisipasi orang tua diperlukan dalam proses sekolah online. Pendek kata orang tua adalah guru, mewakili sekolah, di rumah. Di mana mereka berperan mengadministrasikan pembelajaran dari tahap anak mengerjakan tugas, melaporkan tugas, hingga mengerjakan ujian daring (Cahana Nana : 2020.

Dalam upaya mengendalikan penyebaran pandemi COVID-19, pada pertengahan Maret 2020, pemerintah memutuskan untuk menghentikan sementara kegiatan belajar di sekolah. Sekolah dikhawatirkan dapat menjadi salah satu media yang berpotensi memperluas penyebaran COVID19 karena adanya interaksi secara langsung antara siswa dengan siswa, siswa dengan guru, dan siswa dengan orang tua dengan jarak yang dekat. Pada awalnya, kebijakan penutupan sekolah ini diberlakukan selama dua minggu. Namun, angka penularan pandemi di berbagai daerah yang terus meningkat memaksa sekolah untuk menerapkan kegiatan belajar dari rumah hingga Oktober 2020. Bahkan berkelanjutan hingga memasuki semester berikutnya. Hal ini berdasarkan surat edaran dari Kementrian Pendidikan dan Kebudayaan Nomor 15 Tahun 2020 tentang Pedoman Penyelenggaraan Belajar dari Rumah dalam Masa Darurat Penyebaran Covid-19. Pandemi Covid-19 telah mengubah pola pembelajaran yang semestinya tatap muka menjadi pembelajaran jarak jauh.

Pembelajaran dari rumah yang dilaksanakan pada bulan Maret tahun 2020, mengacu pada surat edaran Kemendikbud No. 40 tahun 2020, tentang pelaksanaan kebijakan pendidikan dalam masa darurat penyebaran covid-19, sebagai upaya untuk memutus mata rantai penyebaran covid-19 di masyarakat terutama di lingkungan sekolah. Aturan ini juga diikuti oleh kebijakan yang di ambil oleh pemerintah daerah termasuk di wilayah Kabupaten Lombok Barat yang menjadi pusat wilayah tempat penelitian dilakukan. Berdasarkan Surat Edaran Bupati Lombok Barat nomor: 440/156/BUP/2020 tanggal 26 Maret 2020 tentang Sistem Aparatur Sipil Negara dalam upaya pencegahan penyebaran covid-19 di Lingkungan Instansi Pemerintah Daerah Kabupaten Lombok Barat. Hal ini kemudian disusul oleh surat edaran dari Kepala Dinas Pendidikan dan Kebudayaan Kabupaten Lombok Barat Nomor 800/594/Dikbud/2020 tanggal 15 April 2020 tentang edaran pencegahan penyebaran Corona Virus Disease (covid-19), Nomor 800/683sekr/Dikbud/2020 tanggal 15 April 2020 tentang Panduan Pelaksanaan pembelajaran dari rumah (study athome) masa darurat penanggulangan penyebaran virus corona (Covid-19) tahun 2020. Kebijakan ini memaksa adanya perubahan pembelajaran yang semula tatap muka antara guru dan siswa menjadi pembelajaran dari rumah.(Jurnal Kelas V SDN 01 Jatisela).

Proses belajar dari rumah dilaksanakan dengan ketentuan: Pertama, belajar dari rumah melalaui pembelajaran daring atau jarak jauh dilaksanakan untuk memberikan pengalaman belajar yang bermakna bagi siswa, tanpa membebani tuntutan menuntaskan seluruh capaian kurikulum untuk kenaikan kelas maupun kelulusan.Kedua,belajar dari rumah dapat difokuskan pada pendidikan kecakapan hidup antara lain mengenai pandemi covid-19, Ketiga, aktifitas dan tugas pembelajaran belajar dari rumah dapat bervariasi antar siswa, sesuai minat dan kondisi masing-masing, termasuk mempertimbangkan kesenjangan akses atau fasilitas belajar dirumah, Keempat, bukti atau produk aktifitas belajar dari rumah diberi umpan balik yang bersifat kualitatif dan berguna dari guru, tanpa diharuskan memberi skors atau nilai kuantitatif (Kemendikbud: 2020)

Pemerintah juga mengharapkan program pembelajaran dari rumah dapat memperluas akses layanan pendidikan bagimasyrakat di daerah terdepan, terluar, dan tertinggal (3T) yang memiliki keterbatasan akses internet ataupun keterbatasan ekonomi. TVRI merupakansaluran gratis yang bisa dinikmati masyrakat diberbagai daerah dan bisa dimanfaatkan oleh siswa, guru dan orang tua untuk membantu pembelajaran dari rumah selama pandemi covid-19, hal ini sebagai respon cepat atas komplain masyrakat di daerah yang tidak memiliki akses internet dan masukan dari komisi X DPR saat rapat kerja pada 27 Maret lalu. (Kemendikbud:2020)

Saat ini pemerintah menerapkan era baru atau new normal termasuk di sektor pendidikan. Lembaga pendidikan wajib mentaati segala peraturan kebijakan pemerintah dan menerapkan protokol kesehatan corona virus 19, jika pemerintah akan membuka kembali aktivitas pendidikan dimasa new normal. Corona virus dalam empat bulan ini masih belum berakhir, maka perlu persiapan yang matang, ternyata dengan persiapan pendidikan yang dibuka pertengahan bulan menuai polemik di beberapa pihak khususnya orang tua siswa. (Cahyadi,nurdin:2020

Widayati (Widayati,Tri:2018) menjelaskan bahwa peran orang tua dalam keluarga terdiri dari: a)Peran sebagaipendidik, orang tua perlu menanamkan kepada anak-anak arti penting pendidikan dan ilmu pengetahuan yang mereka dapatkan darisekolah. b)Peran sebagai pendorong, sebagai anak yang sedang menghadapi masa 
peralihan, anak membutuhkan dorongan orang tua untuk menumbuhkan keberanian dan rasa percayadiri dalam menghadapi masalah.

c)Peran sebagai panutan, orang tua perlu memberikan contoh dan teladan bagi anak, baik dalam berkata jujur maupun dalam menjalankan kehidupan sehari-hari dan bermasyarakat. d)Peran sebagai teman, menghadapi anak yang sedang menghadapi masa peralihan. Orang tua lebihsabar dan mengerti tentang perubahan anak. Orang tua dapat menjadi agen informasi, teman bicara atau teman bertukar pikiran tentang kesulitan atau masalah anak, sehingga anak merasa nyaman dan terlindungi. e)Peran sebagai pengawas, kewajiban orang tua adalah melihat dan mengawasi sikap dan perilaku anak agar tidak keluar jauh dari jati dirinya, terutama dari pengaruh lingkungan baik dari lingkungan keluarga, sekolah dan masyarakat. f)Peran sebagai konselor, orang tua dapat memberikan gambaran dan pertimbangan nilai positif dan negatif sehingga anak mampu mengambil keputusan yang terbaik.

Menurut Ni'mah(Ni'mah : 2016) tanggung jawab pendidikan Islam yang menjadi beban orang tua sekurang-kurangnya harus dilaksanakan dalam rangka: 1) Memelihara dan membesarkan anak. Ini adalah bentuk yang paling sederhana dari tanggung jawab setiap orang tua dan merupakan dorongan alami untuk mempertahankan kelangsungan hidup manusia. 2) Melindungi dan menjamin kesehatan baik jasmaniah maupun rohaniah dari berbagai gangguan penyakit dan penyelewengan dari tujuan hidup yang tidak sesuai dengan falsafah hidup dan agama yang dianutnya. 3) Memberi pelajaran dalam arti yang luas sehingga anak memperoleh peluang untuk memiliki pengetahuan dan kecakapan seluas dan setinggi mungkin yang dapat di capainya. 4) Membahagiakan anak, baik di dunia maupun di akhirat sesuai dengan pandangan dan tujuan hidup muslim.

Imron (Imron,Ali : 2016) mengemukakan pentingnya pendidik yang menurut beliau mencakup "mu"allim" (guru), ayah dan ibu, tokoh masyarakat (musyarrafijtima"i) untuk membina anak dengan hal-hal yang sesuai dengan ajaran agama, terutama dalam hal kepribadian anak baik fisik, psikis atau intelektual yang nantinya dapat dikembangkan. Hal tersebut merupakan tanggung jawab pendidikan terbesar bagi para orang tua, yaitu: 1) Tanggung Jawab Pendidikan Jasmani atau fisik 2) Tanggung Jawab Pendidikan Intelektual/Aqliyah 3) Tanggung Jawab Pendidikan Rohani/Kejiwaan.

Menurut Valeza, (Valeza, Alsi Rizkia : 2017) ada beberapa faktor yang mempengaruhi orang tua dalam melakukan bimbingan belajar pada anak di rumah, diantaranya yaitu: a) Latar Belakang Pendidikan Orang tua b) Tingkat Ekonomi Orang tua c) JenisPekerjaan Orang tua d) Waktu yang Tersedia e) Jumlah Anggota Keluarga.

Berbagai permasalahan yang timbul karena adanya konsekuensi sistem pembelajaran yang berubah menjadi hal yang tak dapat dihindari. Keterbatasan pengetahuan akan penggunaan teknologi, ketersediaan fasilitas penunjang dan penyalahgunaan teknologi pembelajaran oleh siswa menjadi kendala dalam system pembelajaran daring ini (Mappanyompa, 2019).

Berdasarkan penelitian Cahyati Nika, Rita Kusumah (2020) dalam penelitiannya yang berjudul "Peran Orang Tua Dalam Menerapkan Pembelajaran Di Rumah Saat Pandemi Covid 19, menyebutkan bahwa peran orang tua sangat di perlukan untuk proses pembalajaran anak selama study from home ini, peran orang tua juga sangat diperlukan utuk memberikan edukasi kepada anak-anaknya yang masih belum bisa memahami tentang pandemi yang sedang mewabah untuk tetap berdiam diri dirumah agar tidak terlular dan menularkan wabah pandemi ini. Orang tua merasa pembelajaran di rumah sangat efektif untuk diterapkan namun bukan berarti pembelajaran di sekolah tidak lebih efektif dibandingkan dengan kegiatan pembelajaran di rumah.Tujuan Penelitian ini adalah untuk mengetahui peran orang tua dalam menerapkan pembelajaran di rumah saat pandemi covid 19 yang di fokuskan untuk anak usia 5-8 tahun. Metode penelitian menggunakan metode kualitatif fenomenologis, data di peroleh melalui angket, populasi dari penelitian ini adalah orang tua yang memiliki anak usia 5-8 tahun, sampel penelitian ini adalah orang tua yang memiliki anak usia 5-8 tahun di Kabupaten Kuningan. Hasil dari penelitian ini adalah orang tua dapat meningkatkan kelekatan hubungan dengan anaknya dan orang tua dapat melihat langsung perkembangan kemampuan anaknya dalam belajar. (jurnal Hamzanwadi : diakses 10 Maret 2021 pukul 10.15 Wita)

Sejalan dengan penelitian tersebut di atas, Lilawati,Agustin (2020), melakukan studi terhadap Peran Orang Tua dalam Mendukung Kegiatan Pembelajaran di Rumah pada Masa Pandemi. Studi yang dilakukan dengan tujuan mendiskripsikan peran orangtua yang dilaksanakan untuk mendukung kegiatan pembelajaran pada pendidikan anak usia dini di RA Team Cendekia Surabaya. Metode penelitian yang digunakan adalah kualitatif dengan pendekatan studi kasus. Pengumpulan data melalui wawancara, observasi, serta dokumentasi dengan analisis data deskriptif. 
Teknik analisis data terdiri dari reduksi data, sajian data, dan penarikan simpulan. Hasil penelitian menunjukkan bahwa (1) peran orang tua terhadap penerapan pembelajaran di rumah pada masa pandemi dalam mendidik anak meliputi pendampingan dan sebagai motivator. (2) dampak peran orang tua terhadap pembelajaran pada masa pandemi di RA Team Cendekia Surabaya, orangtua memfasilitasi keterlibatan kegiatan pembelajaran dalam pendidikan anak usia dini di RA Team Cendekia Surabaya. (jurnal Obsesi : diakses 10 Maret 2021 pukul 10.25 Wita )

Fikri Sabiq Ahmad dalam Jurnal Ilmu Pendidikan PKn dan Sosial Budaya" ISSN 25799924 (2020) berjudul " Persepsi Orang Tua Siswa tentang Kegiatan Belajar di Rumah sebagai Dampak Penyebaran Covid 19" dengan mengambil objek penelitian di SD Plus Tahfizhul Quran (PTQ) Annida Salatiga, menyatakan bahwa, penyebaran virus corona atau covid 19 berdampak besar pada berbagai sektor kehidupan. Ini termasuk pendidikan dimana siswa belajar di rumah untuk waktu yang lama dengan bantuan orang tua. Penelitian ini bertujuan untuk menggali dan mengungkapkan persepsi orang tua dalam proses mendampingi anaknya di rumah. Metode penelitian ini menggunakan metode kualitatif. Untuk memperoleh data, peneliti menggunakan kuesioner yang diisi dengan sampel orang tua siswa melalui stratified random sampling. Analisis data dilakukan dengan metode deskriptif, yaitu mendeskripsikan data setelah dikelompokkan dan dianalisis. Dari penelitian ini didapatkan data bahwa mayoritas orang tua merasa nyaman dengan program studi di rumah. Mereka juga berharap virus ini segera usai sehingga anak-anak bisa bersekolah kembali. Banyak orang tua mengalami kesulitan dalam mendampingi anaknya belajar di rumah. Hikmahnya, orang tua bisa lebih dekat dengan keluarganya karena memiliki banyak waktu tinggal di rumah serta melatih kesabaran dalam mendampingi pembelajaran dan mengetahui dan memahami pekerjaan seorang guru di sekolah. (jurnal STKIP PGRI : diakses 10 Maret 2021 pukul 10.35 Wita)

Dari permasalahan di atas, terkait dengan peran orang tua dalam pembelajaran dari rumah di masa pandemi covid-19, kendala yang dihadapi serta strategi yang digunakan dalam melakukan pendampingan belajar bagi putra-putri mereka, peneliti tertarik untuk melakukan penelitian yang berjudul,“Peran Orang TuaDalamPembelajaran Dari Rumah Masa Pandemi Covid-19di BTN GriyaPraja Asri DesaJatisela".

Berdasarkan konteks penelitian di atas maka dapat dirumuskan masalah sebagai berikut:
Bagaimana peran orang tua dalam pembelajaran dari rumah masa pandemi Covid-19 di BTN Griya Praja Asri Desa Jatisela?

\section{B. METODE PENELITIAN}

\section{TahapanPenelitian}

Tahapan metodologi penelitian Peran Orang Tua Dalam Pembelajaran Dari Rumah Masa Pandemi Covid-19 peneliti melakukan pengumpulan data baik data primer maupun data sekunder yang berkaitan dengan penelitian ini. Untuk menjamin validitasdata, digunakan teknik triangulasi. Triangulasi merupakan suatu pendekatan analisa data yang mensintesa data dari berbagai sumber (Bachri, 2010). Pada penelitian ini, pengecekan validitas data menggunakan triangulasi sumber. Triangulasi sumber dilakukan untuk mengumpulkan data sejenis dari sumber yang berbeda-beda.

Sumber data premier dalam penelitian ini adalah orang tua sedangkan sumber data sekunder diperoleh dari keterangan kepala sekolah, guru, dan siswa sebagai data triangulasi yang mempunyai hubungan dengan peran orang tua dalam proses belajar dari rumah. Selain itu data sekunder juga diperoleh dari pemerintah Desa Jatisela tempat penelitian ini berlangsung. Pengumpulan data dilakukan dengan cara melakukan observasi (pengamatan), interview (wawancara), serta dokumentasi dan gabungan dari ketiga teknik tersenut. Selanjutnya peneliti mengolah data hasil penelitian dan dijabarkan melalui hasil pembahasan dan kemudian mengambil kesimpulan terkait penelitian yang dilakukan.

Adapun bentuk interview yang digunakan adalah bentuk terstruktur yang bertujuan menjaring data tentang berbagai hal mengenai peran orang tua, kendala dan strategi yang dilakukan dalam mendampingi siswa belajar dari rumah.

Langkah-langkah yang dilakukan peneliti dalam analisa data adalah:

a. Peneliti akan mereduksi data yang mencakup proses memilah, menfokuskan, menyederhanakan, mengabstraksi, dan mentransformasikan data kasar yang diperoleh dari lapangan. Hasil yang dicapai dari reduksi data ini adalah data yang lebih mudah dikendalikan dan memberi gambaran yang lebih tajam.

b. Peneliti akan mendisplay data yang mencakup kegiatan mendeskripsikan, termasuk didalamnya membuatkan berbagai macam matriks, grafik, dan bagan sepanjang diperlukan 
untuk semakin memperjelas pemahaman terhadap deskripsi yang dikemukakan. Dari berbagai data dan temuan dilapangan kemudian peneliti mendiskripsikan dalam bentuk narasi.

c. Selanjutnya, peneliti mengambil kesimpulan dengan berpijak pada pola, tema, hubungan, persamaan, hal-hal yang kerap muncul, dan lain-lain. Kesimpulan pada awalnya bersifat tentatif, dan terus diverifikasi, baik dengan pencarian data baru maupun dengan mendiskusikan temuan yang ada dengan pihakpihak yang berkompeten dan atau dapat membantu

\section{HASIL DAN PEMBAHASAN}

a) Peran orang tua dalam pembelajaran dari rumah masa pandemi Covid-19

Khairani menuliskan bahwa peran merupakan sesuatu yang kompleks dan merupakan pengharapan manusia terhadap cara individu harus bersikap dan berbuat dalam situasi tertentu yang berdasarkan status dan fungsi sosialnya sebagaimana peran dalam kamus oxford Dictionary diartikan dengan Actor"s Part, One"s Task of Function yang berarti aktor, tugas seseorang atau fungsi.(Khairani,Wardina : 2019)

Dalam skripsinya, Heriyani menyebutkan bahwa Orang tua memegang peranan yang penting dan sangat berpengaruh atas pendidikan anak-anaknya. Seorang ayah berperan mengelola dan mengatur seluruh urusan anak serta memberi arah-arahan yang tepat dan berguna. Seorang ayah juga berkewajiban untuk mencari nafkah bagi keluarganya dan juga berkewajiban untuk mencari tambahan ilmu bagi dirinya,karena dengan ilmu-ilmu itu dia akan dapat membimbing dan mendidik dirinya sendiri dan keluarga menjadi lebih baik. Demikian halnya seorang ibu, disamping memiliki kewajiban untuk mencari ilmu karena ibulah yang selalu dekat dengan anak-anaknya.(Heriyani :2010)

Tamsari dalam penelitiannya menemukan (Warsito:2014) bahwa dukungan yang diberikan oleh keluarga terutama orang tua dapat mempengaruhi pembentukan karakter siswa.Dukungan tersebut dapat berupa kasih sayang, perhatian, serta bimbingan yang diberikan kepada anak. Sebagaimana diketahui kegiatan pembelajaran daring yang berlangsung sangat lama menyebabkan anak menjadi bosan dan tidak semangat dalam belajar. Dalam hal ini peran orang tua sangat dibutuhkan dalam memberikan perhatian dan dorongan motivasi kepada anak.Berdasarkan hasil penelitian, kebanyakan dari orang tua siswa memberikan motivasi dalam belajar siswa. Peran orang tua memiliki pengaruh positif pada motivasi siswa. Kontribusi terbesar dari peran orang tua adalah penyediaan fasilitas belajar, termasuk buku pendukung belajar, ruang belajar yang tepat (Alfiansyah, 2019)

Berdasarkan hasil penelitian yang dilakukan terkait peran orang tua dalam proses pembelajaran siswa dari rumah di BTN Praja Griya Asri Desa Jatisela diperoleh hasil terkait peran orang tuaterhadap proses belakjar siswa dari rumah di masa pandemi covid-19.

\section{b) Hasil penelitian}

Dari populasi orang tua yang mendampingi anaknya belajar dari rumah di BTN Praja Griya Asri Desa Jatisela, sepuluh sampel menyatakan berbagai peran yang dilakukan selama proses belajar siswa dari rumah. Diantaranya orang tua berperan sebagai sebagai penyedia fasilitas belajar sekaligus sebagai pembimbing dan pengawas aktivitas belajar mereka. Orang tua bahkan menggantikan peran guru dirumah dengan menyediakan waktu khusus untuk membimbing putra-putri mereka terkait pembelajaran dan tugas atau latihan yang diberikan guru kepada siswa. Selain itu peran orangtua juga dibutuhkan siswa untuk memberikan semangat; motivasi; mengarahkan anak sesuai dengan bakat dan minat yang dimiliki oleh masing-masing anak.

Wawancara yang dilakukan dengan salah satu orang tua siswa di BTN Griya Praja Asri Desa Jatisela, Saleh Ending, mengatakan bahwa peran sebagai orang tua dalam kegiatan belajar anak dari rumah adalah harus bisa menjadi dokter pertama bagi anak-anaknya, dengan cara menjaga kesehatan anak, dengan selalu memastikan menggunakan masker saat berada di luar ruangan serta memberikan edukasi kepada mereka tentang pentingnya menjaga kebersihan lingkungan melalui edukasi tersebut dapat diberikan kepada anak dengan selalu mematuhi protokol kesehatan seperti selalu memakai masker, jauhi kerumunan/menjaga jarak dengan teman-teman dan selalu mencuci tangan selesai beraktivitas. Selain itu orang tua harus bisa menjadi fasilitator bagi pembelajarananak di rumah dengan menyiapkan sarana prasarana yang memadai di rumah, seperti koneksi internet yang stabil serta ruangan yang tenang dan kondusif untukbelajar, sediakan makanan bergizi agar otak dan fisiknyasehat, kuat untuk melakukan proses belajar, selalu bertanya pada anak-anak tentang hal-hal yang ia butuhkan selama belajar di rumah. 
Mungkin ia perlu membeli buku-bukuyang berkaitan dengan materi karena kondisi seperti ini untuk meminjam buku di perpustakaan dan diteman susah. Atau bisa juga memberikan privat tambahan secara online untuk memahami pelajaran yang tidak bisa diajarkan orang tua. (Saleh Ending : 2021)

Ibu Julifah, juga salah satu orang tua siswa di BTN Griya Asri Desa Jatisela mengungkapkan bahwa peran orang tua selama proses belajar dari rumah juga bisa sebagai teman buat anak-anak karena terbatasnya komunikasi dengan orang lain, waktu seperti ini harus digunakan untuk mendekatkan diri dengan anggota keluarga, familytime lebih banyak. Menurut nya, orang tua harus memberikan kasih sayang kepada anaknya tidak hanya melalui pendidikan dan kepercayaan, tetapi juga penting untuk selalu mengontrol perkembangan anaknya. Salah satu cara orang tua untuk tetap mengontrol perkembangan anak kita harus memperbanyak komunikasi yang nyaman dengan anak. Kenyamanan komunikasi seperti inilah maka anakanak akan membuat lebih terbuka kepada orang tua(Julifah :2021).

Siti Halimah juga mengatakan bahwa orang tua juga berperan sebagai Motivator yang dibutuhkan untuk selalu memberikan dukungan pada putra/putrinya agar memiliki semangat belajar serta memperoleh prestasi yang baik, disamping peran diatas,menurutnya orang tua juga sebagai Pengarah/Director bagi putra-putrinya dalam mendampingi proses belajar anak di rumah. (Siti Halimah : 2021)

Hal ini diperkuat oleh pernyataan kepala sekolah, guru dan siswa SDN 01 Jatisela sebagai data triangulasi terkait pembelajaran dari rumah. Bahwa peran orang tua sangat signifikan dalam mendampingi proses belajar dari rumah, menambah pengetahuan terkait pendampingan anak dan meluangkan waktu khusus bagi mereka. Siswa juga berharap orang tua lebih memahami kondisi pembelajaran dari rumah serta berharap memenuhi segala kebutuhan mereka terkait pembelajaran.

\section{SIMPULAN}

Berdasarkan penelitian yang telah dilakukan, peneliti dapat menyimpulkan bahwa dalam proises pembelajaran dari rumah peran orang tua sangat dibutuhkan oleh siswa sebagai penyedia fasilitas belajar, pembimbing, motivator, sekaligus pengarah siswa dalam menemukan minat dan bakat mereka.

\section{DAFTAR RUJUKAN}

Alfiansyah, H. R. (2019). The role of parental involvement towards the students' learning motivation. Lentera Pendidikan : Jurnal Ilmu Tarbiyah Dan Keguruan 22 (2), 276. https://doi.org/10.24252/lp.2019v22n2i9 di akses 12 Maret 2021, pukul 14.21 Wita

Bachri, B. S. (2010). Meyakinkan validitas data melalui triangulasi pada penelitian kualitatif. Teknologi Pendidikan. 10 (1)

Cahana, Nana. 2020. Pembelajaran Daring dan Peran Ganda Orang tua. Kompasiana. Diakses 6 Mei 2021 Pukul 14.25 Wita

Cahyadi, Nurdin. 2020. Pengaruh Corona Terhadap Dunia Pendidikan. disdik.purwakartakab.go.id. di akses 22 Maret 2021, pukul 11.30 WITA

Heriyani. 2010. Peran Orang Tua dalam Membimbing Belajar Anak Mata Pelajaran Pendidikan Agama IslamSiswa Kelas IV MI Ma"arif Banjarparakan Kecamatan Rawalo KabupatenBanyumas Tahun Pelajaran 2009/2010. Purwokerto

http://www.e-journal.hamzanwadi.ac.id/index. php/iga/article/view/2203 diakses 10 Maret 2021 pukul 10.15 Wita

https://obsesi.or.id/index.php/obsesi/article/view/63 0 diakses 10 Maret 2021 pukul 10.25 Wita

http://publikasi.stkippgribkl.ac.id/index.php/CC/article/view/322 diakses 10 Maret 2021 pukul 10.35 Wita

https://www.kemdikbud.go.id/main/block/2020/04/k emendibud-hadirkan-programtayanganbelajar-dari-rumah-di-tvri, 22 Maret 2021 , pukul 12.45 WITA

Imron, Ali. 2016. Pendidikan Kepribadian Anak Menurut Abdullah Nashih Ulwan. Jurnal Edukasi Islamika, Tahun 2016.

Julifah, Wawancara hari Sabtu tanggal 10 Maret 2021 Jurnal Kelas V SDN 01 Jatisela

Kemendikbud, SE Mendikbud: Pelaksanaan Kebijakan Pendidikan dalam MasaDarurat Penyebaran Covid19,http://www.kemdikbud.go.id/main/bl ock/2020/03/se-mendikbud pelaksanaankebijakan-pendidikan-dalam-masa-daruratpeneybaran-covid19, diakses 22 Maret2021, pukul 12.25 WITA

Khairani, Wardina. 2019. Peran Orang tua Terhadap Penggunan Media Internet Dalam Perilaku Keagamaan Anak (Studi pada Keluarga Muslim di Kelurahan Bandar Jaya Barat Kecamatan Terbanggi Besar) . Lampung:

Mela Arnani, Mengenal Virus Corona, Masih Keluarga SARS dan MERS SebabkanPneumonia,https://www.kompas.com /tren/read/2020/01/23/102537965/mengen al-virus-coronamasih-keluarga-sars-dan-merssebabkan-pneumonia?page $=$ all, diakses

23 Maret 2021 Pukul 10.30 wita

Ni'mah. Peranan Orang Tua Dalam Membimbing Anak Untuk Melaksanakan Sholat Lima Waktu DiLingkungan Pasar Kahayan Palangka Raya 
(Studi Terhadap Lima Kepala Keluarga yang Berprofesi sebagaiPedagang). Palangkaraya

Saleh Ending, Wawancara hari Sabtu tanggal 23 Maret 2021

Siti Halimah, Wawancara hari Sabtu tanggal 12 April 2021

Valeza, Alsi Rizka. 2017. Peran Orang Tua dalam Meningkatkan Prestasi Anak di Perum Tanjung Raya Permai Kelurahan Pematang Wangi Kecamatan Tanjung Senang Bandar Lampung. UIN Raden Intan Lampung.

Warsito, Samino. (2014). Implementasi Kurikulum dalam Pembentukan Karakter Siswa Kelas III SD Ta'mirul Islam surakarta.

Widayati, Tri. 2018. Peran Orang Tua dalam Mendidik Anak Perempuan Perspektif Pendidikan Islam. Lampung

Mappanyompa. (2019). Penggunaan Media Tiga Dimensi Dalam Meningkatkan Hasil Belajar Atematika Siswa Kelas V MIN 2 Lombok Barat Tahun Pelajaran 2017/2018. Jurnal Prodi PGMI, 4(2). 